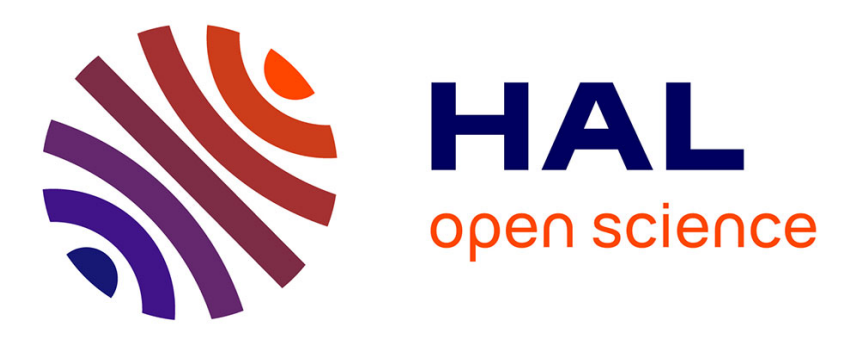

\title{
Better prediction of Mediterranean olive production using pollen-based models
}

Jose Oteros, Fabio Orlandi, Herminia García-Mozo, Fátima Aguilera, Ali

Dhiab, Tommaso Bonofiglio, Mounir Abichou, Luis Ruiz-Valenzuela, M. Trigo, Consuelo Díaz de La Guardia, et al.

\section{To cite this version:}

Jose Oteros, Fabio Orlandi, Herminia García-Mozo, Fátima Aguilera, Ali Dhiab, et al.. Better prediction of Mediterranean olive production using pollen-based models. Agronomy for Sustainable Development, 2014, 34 (3), pp.685-694. 10.1007/s13593-013-0198-x . hal-01234818

\section{HAL Id: hal-01234818 https://hal.science/hal-01234818}

Submitted on 27 Nov 2015

HAL is a multi-disciplinary open access archive for the deposit and dissemination of scientific research documents, whether they are published or not. The documents may come from teaching and research institutions in France or abroad, or from public or private research centers.
L'archive ouverte pluridisciplinaire HAL, est destinée au dépôt et à la diffusion de documents scientifiques de niveau recherche, publiés ou non, émanant des établissements d'enseignement et de recherche français ou étrangers, des laboratoires publics ou privés. 


\title{
Better prediction of Mediterranean olive production using pollen-based models
}

\author{
Jose Oteros • Fabio Orlandi • Herminia García-Mozo • Fátima Aguilera • Ali Ben Dhiab • \\ Tommaso Bonofiglio • Mounir Abichou • Luis Ruiz-Valenzuela • M. Mar del Trigo • \\ Consuelo Díaz de la Guardia • Eugenio Domínguez-Vilches • Monji Msallem • \\ Marco Fornaciari • Carmen Galán
}

Accepted: 6 November 2013/Published online: 5 December 2013

(C) INRA and Springer-Verlag France 2013

\begin{abstract}
Olive oil is a major economic resource of the Mediterranean region. Olive crop management can be improved by models that forecast the variable reproductive biology of olive tree. However, the processes controlling olive harvest are complex on large scales. Here, we study the parameters that influence olive fruit production for developing accurate forecasting models. Seventeen aerobiological sampling points have monitored olive pollen grains in Spain, Italy and Tunisia from 1993 to 2012. Six crop models have been developed at two provinces and country scales. The modelling has been done in two steps: (1) typification and (2) modelling by partial least square regression. Results show that higher pollen indexes and water availability during spring are related to an
\end{abstract}

J. Oteros $(\bowtie) \cdot H$. García-Mozo • E. Domínguez-Vilches · C. Galán Department of Botany, Ecology and Plant Physiology, Agrifood Campus of International Excellence (CeiA3), University of Córdoba, 14071 Cordoba, Spain

e-mail: b42otmoj@uco.es

F. Orlandi $\cdot$ T. Bonofiglio $\cdot$ M. Fornaciari

Department of Applied Biology, University of Perugia,

Borgo XX Giugno 74, 06121 Perugia, Italy

F. Aguilera $\cdot$ L. Ruiz-Valenzuela

Department of Animal Biology, Plant Biology and Ecology,

Agrifood Campus of International Excellence (CeiA3),

University of Jaén, 23071 Jaén, Spain

\author{
A. B. Dhiab · M. Abichou • M. Msallem \\ Institut de l'Olivier, B.P. 208, 1082 Tunis, Tunisia \\ M. M. del Trigo \\ Department of Plant Biology, University of Malaga, \\ P.O. Box 59, 29080 Malaga, Spain \\ C. Díaz de la Guardia \\ Department of Plant Biology, University of Granada, \\ 18071 Granada, Spain
}

increase of final fruit production in all the studied area. Higher pollen indexes are also positively correlated with air temperature during early spring and autumn. Furthermore, a decrease of fruit production is related with increasing air temperature during winter and summer. To conclude, we have designed accurate models that allow accurate predictions of olive production.

Keywords Olea europaea · Crop · Pollen · Aerobiology · Crop forecasting $\cdot$ Mediterranean

\section{Introduction}

Olive (Olea europaea L.) is one of the most extensive crops in the Mediterranean basin (Fig. 1). Olive fruit and oil are among the most important products for the economy of this area (Lavee 1996). Indeed, $95 \%$ of the total area under olive production is concentrated in the Mediterranean basin. Olive cultivation is believed to have originated about 6,000 years ago in the Middle East (now Israel). The profitability of the cultivation of olive is mainly obtained from olive oil production ( $90 \%$ of the economic benefit), and hence less so from the commerce of fresh fruit (Vossen 2007; Barranco et al. 2008).

Early and effective crop forecasting is essential for optimisation of technical and human resources for olive harvesting and for planning global marketing and commercial distribution of olive oil. Nowadays, crop fruit production has been forecasted using several methods, such as crop growth monitoring system models, time trends or based on satellite measurements (Palm 1995; Bastiaanssen and Ali 2003; Fei et al. 2012). While the most widely used method for crop estimation is by visual observation prior to the harvest, in the case of

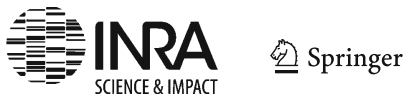




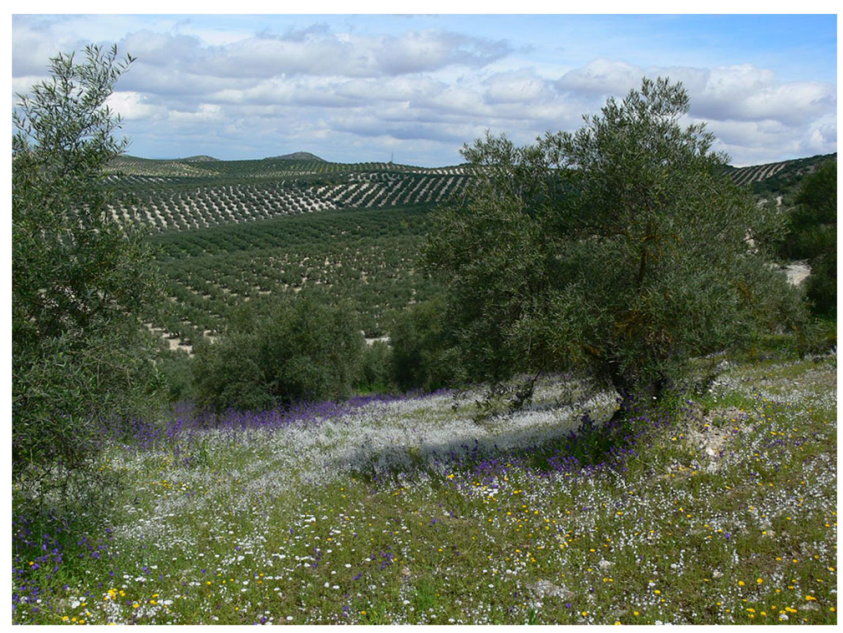

Fig. 1 Olive grove in the South of Córdoba province, where it is the main economical resource. The present paper will improve the productivity of the olive grove in the Mediterranean area

anemophilous species, good results can be obtained by modelling pollen release as an index of the flowering intensity and as a bioindicator of the pollination period (Muñoz et al. 2000; García-Mozo et al. 2012). In anemophilous species, the annual airborne pollen has been demonstrated to be a good indicator of flowering intensity and timing during certain phenological stages (Keynan et al. 1989; Aguilera and Ruiz-Valenzuela 2009; León-Ruiz et al. 2011). Nevertheless, there are other external parameters that also affect different essential processes on fruit production including in particular the weather, but also pollination, fruit setting, fruit fattening and the favourability for pests. Therefore, different studies on olive production have included meteorological variables in combination with annual airborne pollen to obtain more accurate indications (Galán et al. 2008; Orlandi et al. 2010).

The present study has been designed to identify the main abiotic parameters that influences more olive fruit production in three of the main olive-producing countries of the world: Spain, Italy and Tunisia and also to develop accurate forecasting models of crop production in several areas of the Mediterranean basin. In general, the areas devoted to this crop in those countries have a Mediterranean climate, which is characterised by hot, dry summers and mild, rainy winters. However, this climate area is also characterised by marked year-on-year variations in the weather patterns with great spatial variability. On the other hand, the Mediterranean basin has been identified as one of the most affected areas of the world in future climate change projections. Knowledge about the abiotic parameters that contribute more to crop production in this area can offer important information to predict the potential impacts of climate change (IPCC WGII 2007; Giorgi and Lionello 2008; Lavalle et al. 2009; Sicard et al. 2012; Orlandi et al. 2013).

One objective of this paper has been to propose three integrated national models for olive fruit production in the
Mediterranean basin at country scale for Spain, Italy and Tunisia taking into account both different meteorological and airborne pollen parameters for modelling with a novel statistical methodology. A second goal has been focus to construct forecasting models at province scale to provide accurate models that can be better adapted to different crops, cultivars or weather conditions, where different abiotic parameters can play an important role.

\section{Materials and methods}

Different variables were taken into account in this study, including airborne olive pollen counts, meteorological parameters and agronomic reports over the last 20 years (19932012). The studied areas stretch across the Mediterranean basin and included three of the main olive oil production countries in the world (up to $66.5 \%$ of world production): Spain (47 \%), Italy (14.5\%) and Tunisia (5 \%) (IOC 2011).

In these countries, the main olive-growing areas have been airborne pollen monitored. In Spain, these sampling points cover $74 \%$ of the national production: Jaen (41\%), Córdoba (20\%), Granada (8\%) and Malaga (5 \%) (Ssya 2011). In Italy, these sampling points cover $83.2 \%$ of the national production: Umbria (1\%), two in Campania (8 \%), two in Puglia (35\%), one in Calabria (29\%) and two in Sicily (10\%) (ISTAT 2011). In Tunisia, these sampling points cover $97 \%$ of the national production: Mornag (23\%), Sahel (22\%), Menzel M'Hiri (20\%), Sfax (25\%) and Medenine (7\%) (GDAP 2011).

The studied areas are with different olive cultivars. In the Spanish study area, the principal cultivars are Hojiblanca, Picual, Picudo and Lechín. In Italy, the cultivars in Sicily are Biancolilla and Nocellara; in other areas, the more important cultivars are Frantoio, Carolea and Coratina. In the Tunisian studied areas, the principal cultivars are Chetoui and Chemlali.

The airborne pollen counts represent the total amount of Olea pollen in the air during the pollen season; this variable is termed the Pollen Index (PI). The pollen season start date was defined as the first day in which at least a daily average of 1 pollen grain $/ \mathrm{m}^{3}$ of air was reached, with at least five subsequent days with $\geq 1$ pollen grain $/ \mathrm{m}^{3}$ (García-Mozo et al. 2009). The end of the season was the last day on which 1 pollen grain $/ \mathrm{m}^{3}$ was recorded and when five subsequent days showed $<1$ pollen grain $/ \mathrm{m}^{3}$. In Spain and Italy, airborne pollen were recorded using Hirst-type volumetric traps (Hirst 1952), which were managed according to the standardised rules laid down by the Spanish Aerobiology Network (Galán et al. 2007). In Tunisia, airborne pollen was detected using Cour traps (Cour 1974). The traps have been sited in the administrative capitals of the growing study areas (Fig. 2).

Meteorological data included maximum and minimum daily temperature, daily rainfall, daily solar radiation, 
Fig. 2 Locations of the aerobiological sampling points used in this study

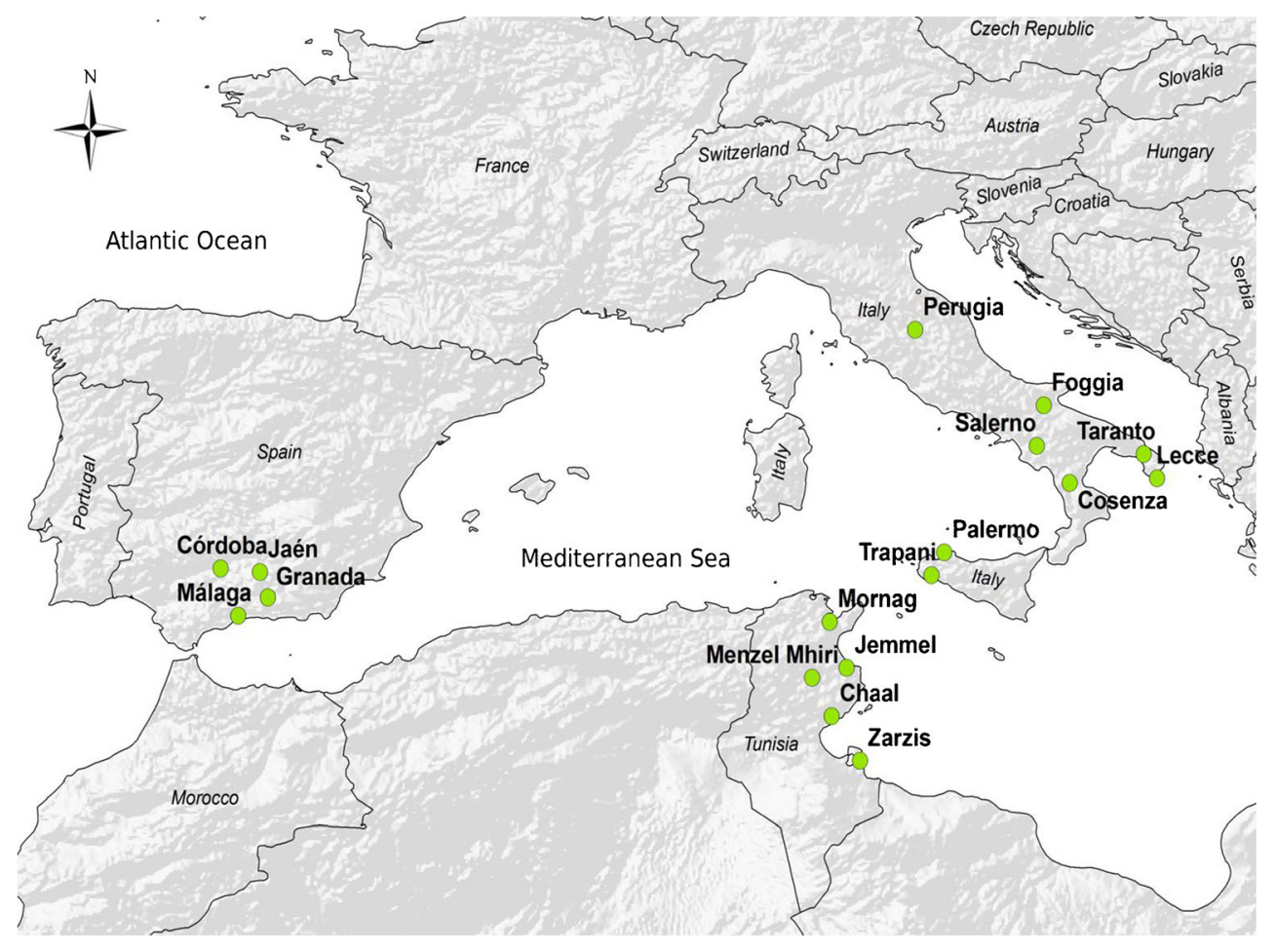

maximum and minimum daily relative humidity and mean daily wind velocity. These parameters were recorded at the weather stations nearest to the aerobiological samplers. The meteorological data from Spain were provided by Andalusian Phytosanitary Information Alert Network (RAIF) and the Spanish Meteorological Agency (AEMET). The Italian meteorological data were obtained from the network stations of the National Council of Agricultural Research (CRA-Cma). In Tunisia, meteorological data were provided by the different stations of the National Meteorological Centre (NIM).

The abiotic variables analysed have been mean, maximum and minimum temperature, cumulated rainfall, evapotranspiration of the olive crop (ETc.), cumulated rainfall minus ETc. and net radiation from 1 year before each harvest. These parameters have been included in the analysis as a global, bi-monthly, monthly, fortnightly or 10-day value.

ETc. was calculated following the Penman-Monteith formula as modified by the Food and Agriculture Organization of the United Nations (FAO; Allen et al. 1998). Different daily parameters have been taken into account for ETc. calculation: maximum and minimum air temperature, mean air temperature, solar radiation, wind speed and maximum and minimum relative humidity. For missing meteorological data estimation, the FAO P-M guide proposal (chapter 3 ) has been followed (Allen et al. 1998). The crop rates proposed by the FAO were used to calculate ETc. (Pastor and Orgaz 1994).

Rainfall and temperature characteristics (Table 1) in each of the study areas share similarities in the Mediterranean climate, although there are some clear differences, i.e. lower annual rainfall and higher temperatures in Tunisia than in Italy and Spain or warmer climate in Spain than in Italy.

In the present study, six models were built based on different area ranges: three national models at country scale for Spain, Italy and Tunisia, and three local models at province scale that represent the central, northern and southern olive growing areas for Cordoba (Spain), Perugia (Italy) and Zarzis (Tunisia), respectively.

Statistical procedure has followed two different steps at both scales; although typification transformation has no effect on the final outcome of the local models:

I. Typification. All study sites are with different biological and meteorological features; however, in the case of national models, several areas have been analysed together. For this purpose, all variables were typified before modelling to prevent any particular sampling point with more weight in the statistical interpretation than the others. To avoid these potential errors, the following typification formula has been applied:

$Z_{i}=\left(\frac{X_{i}-\bar{X}}{\sigma}\right)$

where $X_{i}$ is an analysed case of variable $X, Z_{i}$ is the typified value of $X_{i}, \bar{X}$ is the mean value of the variable $X$ and $\sigma$ is the standard deviation of variable $X$. 
Table 1 Rainfall and temperature data for each of the aerobiological sampling points, averaged over the period from 1993 to 2012

\begin{tabular}{|c|c|c|c|c|c|c|c|c|c|c|c|}
\hline \multirow[t]{2}{*}{ Growth area } & \multirow[t]{2}{*}{ Country } & \multirow[t]{2}{*}{ Coordinates } & \multirow{2}{*}{$\begin{array}{l}\text { Altitude } \\
\text { m a.s.1. }\end{array}$} & \multicolumn{5}{|c|}{ Rainfall (mm) } & \multicolumn{3}{|c|}{$\mathrm{T}\left({ }^{\circ} \mathrm{C}\right)$} \\
\hline & & & & JFM & AMJ & JlAS & OND & JFM & AMJ & JlAS & OND \\
\hline Córdoba & Spain & $37^{\circ} 50^{\prime} \mathrm{N}, 4^{\circ} 45^{\prime} \mathrm{W}$ & 123 & 187.4 & 106.2 & 37.5 & 271.6 & 11.6 & 20.9 & 26.9 & 14.3 \\
\hline Jaén & Spain & $37^{\circ} 45^{\prime} \mathrm{N}, 3^{\circ} 47^{\prime} \mathrm{W}$ & 550 & 163.5 & 107.6 & 37.8 & 179.2 & 10.4 & 19.6 & 25.8 & 12.9 \\
\hline Granada & Spain & $37^{\circ} 11^{\prime} \mathrm{N}, 3^{\circ} 35^{\prime} \mathrm{W}$ & 685 & 101.5 & 89.5 & 60.4 & 102.3 & 8.6 & 18.8 & 24.7 & 13.0 \\
\hline Málaga & Spain & $36^{\circ} 47^{\prime} \mathrm{N}, 4^{\circ} 19^{\prime} \mathrm{W}$ & 5 & 189.7 & 74.8 & 23.4 & 254.5 & 13.5 & 20.2 & 25.6 & 16.3 \\
\hline Perugia & Italy & $43^{\circ} 06^{\prime} \mathrm{N}, 12^{\circ} 23^{\prime} \mathrm{E}$ & 450 & 191.4 & 200.6 & 156.1 & 269.2 & 6.8 & 17.7 & 22.8 & 10.4 \\
\hline Foggia & Italy & $41^{\circ} 25^{\prime} \mathrm{N}, 15^{\circ} 33^{\prime} \mathrm{E}$ & 70 & 101.5 & 89.5 & 60.4 & 102.3 & 8.6 & 18.8 & 24.7 & 13.0 \\
\hline Salerno & Italy & $40^{\circ} 31^{\prime} \mathrm{N}, 15^{\circ} 22^{\prime} \mathrm{E}$ & 29 & 302.0 & 146.3 & 141.3 & 299.4 & 9.2 & 17.6 & 21.0 & 12.4 \\
\hline Taranto & Italy & $40^{\circ} 21^{\prime} \mathrm{N}, 18^{\circ} 01^{\prime} \mathrm{E}$ & 48 & 302.0 & 146.3 & 141.3 & 299.4 & 9.2 & 17.6 & 21.0 & 12.4 \\
\hline Lecce & Italy & $39^{\circ} 49^{\prime} \mathrm{N}, 18^{\circ} 21^{\prime} \mathrm{E}$ & 104 & 95.4 & 63.4 & 73.3 & 208.7 & 9.1 & 18.4 & 24.3 & 13.3 \\
\hline Cosenza & Italy & $39^{\circ} 43^{\prime} \mathrm{N}, 16^{\circ} 10^{\prime} \mathrm{E}$ & 150 & 181.4 & 106.7 & 106.3 & 181.2 & 9.8 & 19.0 & 25.1 & 14.1 \\
\hline Palermo & Italy & $38^{\circ} 10^{\prime} \mathrm{N}, 13^{\circ} 05^{\prime} \mathrm{E}$ & 21 & 71.7 & 27.5 & 101.7 & 166.5 & 12.5 & 20.0 & 25.3 & 17.5 \\
\hline Trapani & Italy & $37^{\circ} 40^{\prime} \mathrm{N}, 12^{\circ} 46^{\prime} \mathrm{E}$ & 160 & 146.0 & 54.0 & 46.7 & 201.0 & 11.6 & 19.0 & 25.1 & 16.2 \\
\hline Mornag & Tunisia & $36^{\circ} 39^{\prime} \mathrm{N}, 10^{\circ} 16^{\prime} \mathrm{E}$ & 40 & 158.3 & 84.4 & 56.7 & 173.7 & 12.5 & 21.4 & 27.4 & 16.9 \\
\hline Jemmel & Tunisia & $35^{\circ} 38^{\prime} \mathrm{N}, 10^{\circ} 41^{\prime} \mathrm{E}$ & 30 & 93.8 & 48.4 & 64.3 & 104.6 & 13.7 & 21.4 & 27.4 & 18.3 \\
\hline M.Mhiri & Tunisia & $35^{\circ} 25^{\prime} \mathrm{N}, 09^{\circ} 50^{\prime} \mathrm{E}$ & 160 & 61.8 & 70.6 & 68.1 & 79.3 & 13.7 & 23.1 & 29.5 & 18.1 \\
\hline Chaal & Tunisia & $34^{\circ} 34^{\prime} \mathrm{N}, 10^{\circ} 19^{\prime} \mathrm{E}$ & 97 & 64.6 & 51.3 & 35.2 & 60.7 & 13.4 & 21.6 & 27.4 & 17.9 \\
\hline Zarzis & Tunisia & $33^{\circ} 35^{\prime} \mathrm{N}, 11^{\circ} 01^{\prime} \mathrm{E}$ & 17 & 47.0 & 18.1 & 25.9 & 83.7 & 14.9 & 23.1 & 28.0 & 19.2 \\
\hline
\end{tabular}

JFM January, February, March; AMJ April, May, June; JlAS July, August, September; OND October, November, December

II. Modelling. The models were constructed using the partial least squares regression method (PLSr), taking the crop production as a dependent variable and the different meteorological and aerobiological variables as the independent variables. PLSr is considered as an appropriate statistical technique when a high number of observations and a high number of independent variables are involved in the modelling process. Modelling was based on linear transformation of the original descriptors to a small number of orthogonal factors (latent variables) to maximise the covariance between the descriptors and the dependent variables. PLSr method develops latent variables, like the principal component analysis and prior regression, but they are building with the purpose to explain the dependent variable, i.e. the crop production. In this sense, latent variables are built more efficiently than with other multivariate methods. In this paper, each latent variable represented a key factor for olive crop production. All of the models were validated following the full cross validation method. Unscrambler 9.7 software was used.

\section{Results and discussion}

Some studies have attempted to model the relationship between olive crop production and different airborne pollen and weather variables prior to harvesting (Candau et al. 1998;
González-Minero et al. 1998; Fornaciari et al. 2002, 2005; Orlandi et al. 2003, 2005, 2010; Galán et al. 2004, 2008; Ribeiro et al. 2007, 2008; García-Mozo et al. 2008; Aguilera 2012). This paper tries to improve these studies in two points: in all these studies, linear regression approach for solving the problem has been used; in this study, a novel statistical methodology based on two different steps has been used: (1) typification and (2) modelling by PLSr. This statistical analysis allows to model crop production in several areas at the same time. Being the first time that it is modelling more than one province at the same time, the first models, built at country scale, can provide useful information. On the other hand, thanks to the use of a database with the highest study area and study years so far, it is possible to know the main abiotic parameters responsible for crop production at different scales and to obtain global conclusions.

Only the abiotic control on yield and PI has been taken into account due to PI summarising the percentage of variability explained by other area features like the cultivar. Moreover, the most accurate forecasting model has been at the province level; the heterogeneity in biotic features and anthropogenic management at province and national levels precludes its use as crop yield forecasting variables with scientific purposes. For this reason, it is difficult to know its influence on crop production at a large scale. While management features, like the extensive-intensive management or the fertilisation, must be taken into account when the aim is develop accurate crop yield forecasting models at farm scale. 
Previous studies have shown that PI can be used as a representative index for floral phenology for different cultivars and areas. PI is determined by physiological characteristics of the tree, influenced by the meteorological parameters prior to the flowering period (rainfall, water availability and to a lesser extent, temperature) in the Mediterranean basin (Galán et al. 2001; Oteros et al. 2013a, 2013b). In this sense, the pollen index has been usually the most important parameter in crop-forecasting models (i.e. Galán et al. 2004, 2008). Due to olive trees producing a large excess of pollen with respect to that needed for fertilisation (Barranco et al. 2008), previous studies have been able to define relationships between crop production and PI during shorter periods of time than pollen season; i.e. in the days prior to full flowering or in the period around full flowering (Orlandi et al. 2005; GarcíaMozo et al. 2008; Ribeiro et al. 2008; Cuevas et al. 2009). However, this paper has shown the important role of PI in all the models for crop production. These results have been supported by previous studies (García-Mozo et al. 2008), observing in different occasions better results by considering the annual PI.

Both determination coefficient $\left(R^{2}\right)$ and determination coefficient of the full cross-validation $\left(Q^{2}\right)$ for the different models (Table 2) are higher when lower numbers of explained areas are included in the model, at lower scale. For this reason, the province-scale models (local models) offer better predictions, showing the important role of specific agro-climatic features of a given area for modelling. Figure 3 a shows the local modelling with different variables involved.

In Córdoba model, PI, water availability in spring (rainfall minus crop evapotranspiration from 1 October to 30 April) and mean September temperature have shown positive influences on crop production. In contrast, both mean January temperature and mean July maximum temperature show negative influences on the final crop production. In Perugia model, PI, accumulated rainfall from 1 January to 31 June and mean October minimum temperature showed positive

Table 2 Summary of the partial least squares regression model parameters

\begin{tabular}{llllll}
\hline Model & $N$ & $X$ & SD & $R^{2}$ & $Q^{2}$ \\
\hline Córdoba & 1 & $1,029,203$ & 367,204 & 0.91 & 0.82 \\
Perugia & 1 & 44,352 & 16,517 & 0.95 & 0.85 \\
Zarzis & 1 & 51,298 & 39,233 & 0.92 & 0.83 \\
Spain & 4 & 899,988 & 772,773 & 0.74 & 0.72 \\
Italy & 8 & 121,509 & 103,159 & 0.70 & 0.65 \\
Tunisia & 5 & 153,166 & 101,607 & 0.77 & 0.75 \\
\hline
\end{tabular}

$N$ number of study areas in each model, $X$ mean of the dependent variable, $S D$ standard deviation of the dependent variable, $R^{2}$ determination coefficient of the model, $Q^{2}$ determination coefficient of the full cross validation influences on final crop production. On the other hand, mean January temperature and mean of the maximum temperature in the second 10 days of July show negative influences on crop production. In the Zarzis model, a positive relationship was observed between PI, water availability in spring (rainfall minus crop evapotranspiration from 1 October to 30 April) and March rainfall and crop production, while maximum temperature during the second 10 days of July showed significant negative effect.

In case of national model for Spain (Fig. 3b), PI has been the most important variable. Other variables with positive influences were water availability in spring (rainfall minus crop evapotranspiration from 1 October to 30 April) and the mean September temperature. The average of the maximum temperatures during the first 10 days of May showed a negative effect on the final fruit production. In the Italian model, PI, cumulative rainfall in March, mean of the minimum temperatures during the first 10 days of May and mean September temperature showed positive effects on crop production. In contrast, means of maximum temperatures during the last 10 days of May and during August showed negative influences on the crop production. In the Tunisian model, PI, water availability in spring and mean of the minimum temperatures in the last 10 days of April showed positive influences on crop production. Any variable with a negative effect on the final fruit production has not been observed.

In both the national (at country scale) and local (at province scale) models, the thermal variables were important for fruit production; however, given the variations across these environments and the phenological uncoupling, the local models are better adapted than the national models. Air temperature effect on olive tree productivity varies according to the studied area, depending on different weather contexts throughout the year (Oteros et al. 2013b; Aguilera et al. 2013).

Other authors have shown a negative effect of rainfall on PI during the pollination period due to the wash out by raindrops (Vázquez et al. 2003). This phenomenon have not been noted for olive crop due to only $2 \%$ of effective fruit set is sufficient for an excellent crop yield (Barranco et al. 2008), although in these strange cases the PI would be less related with flowering intensity.

Water availability in autumn and spring (rainfall minus crop evapotranspiration from 1 October to 30 April) is another important variable in most of these models, except in the Perugia local model and the Italy national model. In these cases, water availability variable is replaced by accumulated rainfall between 1 January and 30 June and the accumulated precipitation during March. However, all of these hydric variables can be interpreted in the same general way: good water availability for flowering is a factor that favours crop production in all study areas. Many other studies agree with this result, which relates to the importance of water availability for floral development, arguing that this fact can influence 
Fig. 3 Regression coefficients of the important variables in local models (a) and national models (b). PI pollen index; Rf-Etc. (OctApr) cumulated rainfall from 1 October of the preceding $(n-1)$ year to 30 April minus the evapotranspiration for the olive crop over the same period; Tmn(Jan) mean January temperature; Tmax(Jul) mean daily maximum July temperature; $\operatorname{Tmn}(\mathrm{Sep})$ mean September temperature; Rf(Jan-Jun) cumulated rainfall from 1 January to 30 June; Tmax (2nd_Jul) mean daily maximum temperature for the second 10 days of July; $\operatorname{Tmn}(\mathrm{Oct})$ mean October temperature; $R f($ Mar) cumulated rainfall from 1 to 31 March; Tmax(1st_May) mean daily maximum temperature in the first 10 days of May; Tmin(1st_Mar) mean daily minimum temperature in the first 10 days of March; Tmax(3rd_May) mean daily maximum temperature in the last 10 days of May; Tmax(Aug) mean daily August maximum temperature; $\operatorname{Tmin}\left(3 r d \_A p r\right)$ mean daily minimum temperature in the last 10 days of April

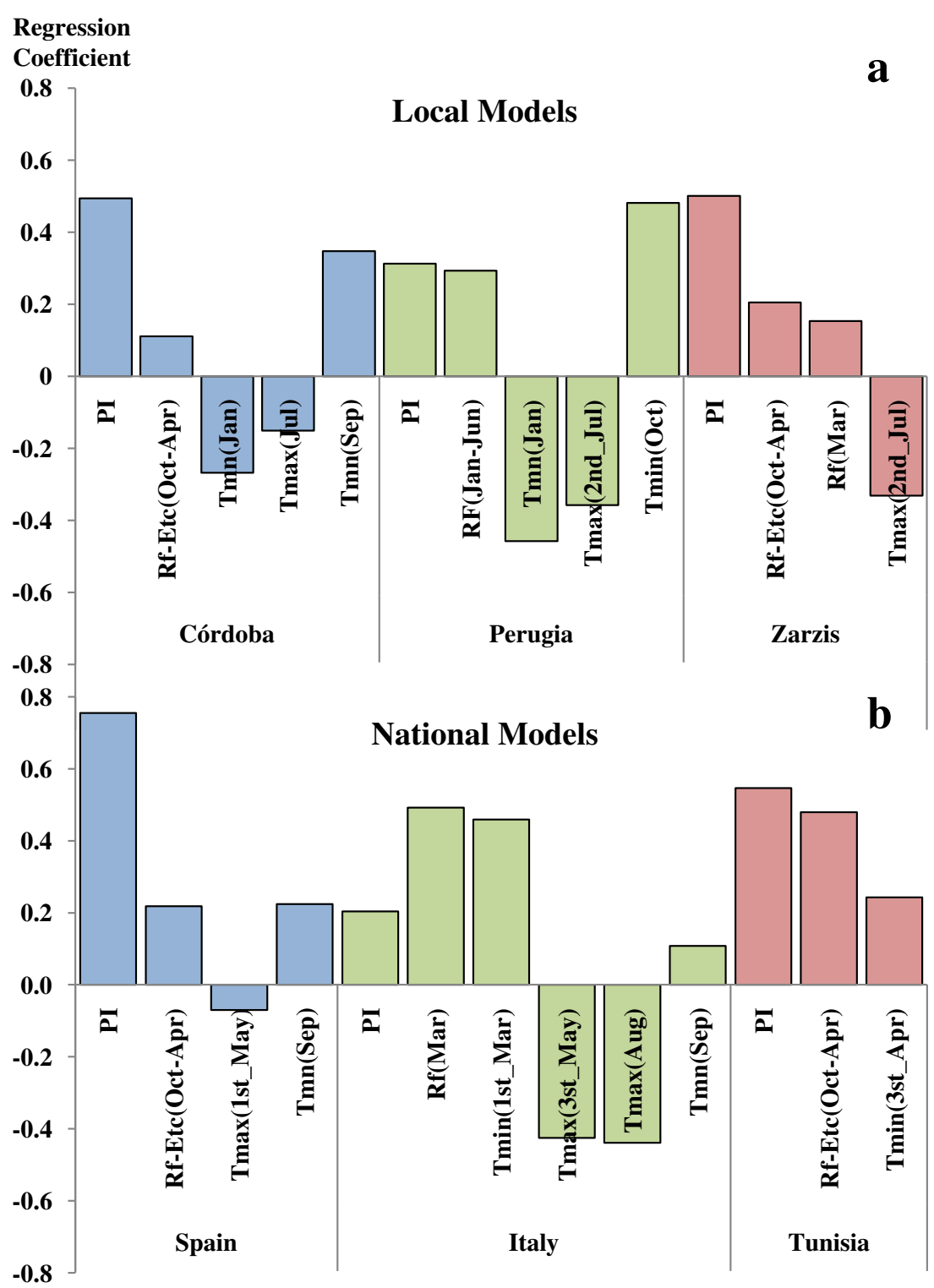

the number of flowers per inflorescence or provide a greater photosynthetic capacity for the plant (Rallo 1994; Candau et al. 1998; Galán et al. 2004, 2008). Other studies have related the importance of water availability in terms of the process of fruit setting and early fruit drop after fecundation (Galán et al. 2008). Indeed, the presence of a water deficit has important impact on the development of the whole plant, which can be observed at the phenological, physiological and production levels (Bacelar et al. 2007, 2009; Barranco et al. 2008; Rapoport et al. 2012).

Air temperature is another important variable in different areas. However, decoupling from the phenological development time means that different effects can be seen for the various analysed areas. On local models for Cordoba and Perugia, the mean January temperature showed a negative influence on crop production. In late autumn and early winter, olive trees undergo a dormancy period when their growth and development are temporarily suspended (Melo-Abreu et al. 2004). Afterwards, a stress situation due to low temperature is required for them to emerge from dormancy, a chilling period (Orlandi et al. 2004; Galán et al. 2005). Other studies have shown negative relationships between temperatures during this dormancy and harvest production (Fornaciari et al. 2005). High temperatures during this period can delay breaking of dormancy, and therefore delay phenological development (Orlandi et al. 2006).

On the other hand, the minimum temperatures recorded during the pre-flowering period showed a positive relationship for crop production on the national model for Italy (the mean minimum temperatures in the first 10 days of May) and the national model for Tunisia (the mean minimum temperatures in the last 10 days of April). Similar relationships have been 
observed in other studies, where it has been maintained that exposure of the olive trees to heat before flowering promotes an increase in the photosynthetic capacity and favours the pollination process (García-Mozo et al. 2008).

Furthermore, higher temperatures during fruit setting showed a negative relationship with crop production in the Spanish model (mean maximum temperatures in the first 10 days of May) and in Italy (mean maximum temperatures in the last 10 days of May). The decoupling of the phenological development time will be the reason for the differences in the periods when temperature affects olive in different geographical areas. Other studies have noted that elevated temperatures during the fruit setting period can lead to excessive fruit drop, and hence lower production yield. Although, during this period, a high fruit abortion rate on olive tree, water deficit and high temperature is normal to accentuate this process (Aguilera 2012).

High temperatures and evapotranspiration during the summer are also causes of increased fruit drop, and hence a decline in the crop production, according to various studies (Ribeiro et al. 2008; Orlandi et al. 2010). The present study has also found this relationship for the local models for Córdoba, Perugia and Zarzis, and also in the national model of Italy.

There is also a positive relationship between autumn temperature and crop production in the local models for Córdoba and Perugia and the national models of Spain and Italy. It has been also observed by other studies manifesting the role of these temperatures on the maturation process (Galán et al. 2008).

In general, the dependent variable shows different relationships with the different predictive parameters depending on the studied areas. In this sense, local models offer optimum forecast potential (Fig. 4). However, national models do provide valuable information about the parameters that affect the different study areas more, revealing the most important variables for olive crop production, and which areas will be more fragile in a changing environment.

With regard to the effectiveness of the models in the present study, it can be seen that they were more accurate in local areas. The reason is the heterogeneity when input data increase due to environmental conditions that can influence plants at different study areas. Weather conditions can act in different ways on the reproductive cycle of olive trees depending on the previous meteorological context, which might have been decisive for the physiological status of the plant (Oteros et al. 2013b).

Nevertheless, wider models can still help to understand responses of olive trees in different agroecosystems and to determine the most important variables affecting olive fruit production. The data from these wider models will therefore help to deepen the knowledge of potential effects of climate change in the Mediterranean basin.
Fig. 4 Yearly crop production as observed and as expected according to the indicated local models; $t$ metric tons. These models were validated using the full cross-validation. As can be seen, these local models can be used effectively for crop forecasting purposes

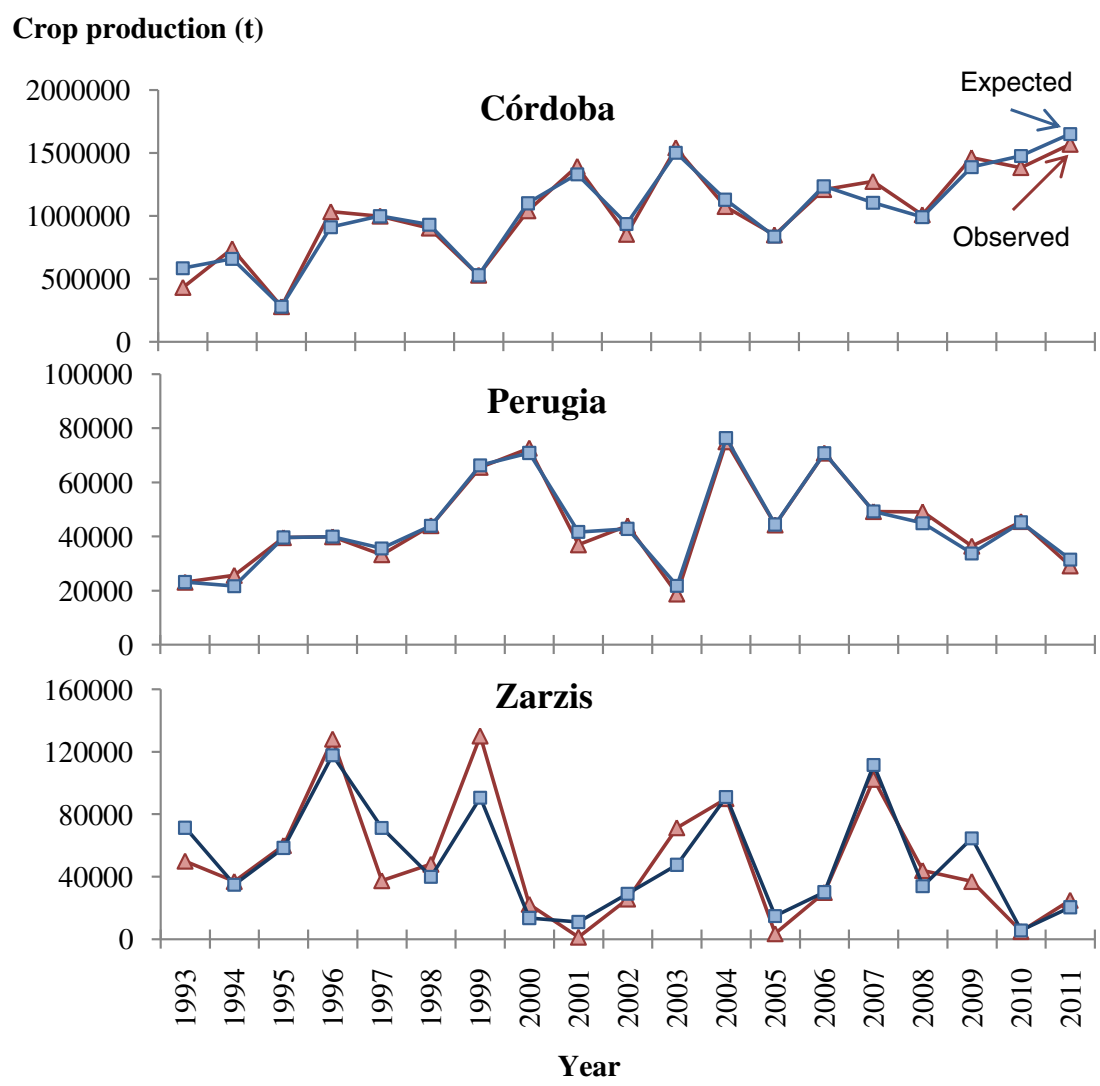


The Intergovernmental Panel on Climate Change (IPCC WGII 2007) proposes several future climatic scenarios based on different estimations of humanity development and climate trends. The A1B emission scenario is the most accepted by the scientific community; this future scenario assumes a rapid increase of greenhouse gas (having about $700 \mathrm{ppm}$ of $\mathrm{CO} 2$ concentration in year 2010). Giorgi and Lionello (2008) use this scenario for concluding that temperatures and evapotranspiration increases in the Mediterranean basin opposite to rainfall that decreases. In this sense, according to present results, olive crop production will tend to decrease although local climatic features can modify the way in which olive trees will respond to climate change. For this reason, the present paper must be taken into account in future studies to confirm this fact.

The data of this study are important for determining actual meteorological requirements of different olive cultivars in the Mediterranean basin where olive cultivation is the main resource for thousands of families and generate great economic wealth each year. Due to the novelty of the statistical approach on crop modelling and the big surface extension analysed in the present paper, the study has improved the results obtained in the present, being of vital importance from the standpoint of environmental, economic and social development in a changing environment.

\section{Conclusions}

The local models had potentially high predictive values, while these predictive values appeared to decrease in national models along with increases in the heterogeneity of the characteristics of the overall study area. In this sense, we propose the use of specific low-scale models better adapted to agroclimatic features with forecasting purposes.

However, national models provide valuable information about the parameters that had greater effects on olive crop forecast in the different study areas and about the areas that will be more fragile in a changing environment.

The pollen index and water availability during spring represented the most significant variables in all models, and they were essential for optimal crop production in the Mediterranean basin. Temperature has been another significant parameter in the models with clear positive effects on crop production during the period prior to flowering and during autumn, and with negative effects on crop production during the process of fruit setting in winter and then during summer.

This study has improved all the previous crop modelling studies under aerobiological approach in a statistical sense and on the spatial extrapolation of conclusions, providing a partial least square regression analysis applied to a broader Mediterranean surface, i.e. the largest olive growing area in the world. The present paper proposes a new approach that improves all previous studies. This new statistical approach shows better results than with previous olive crop models based on linear regression; it should be taken into account for future crop modelling studies in different agroecosystems.

Acknowledgments The authors are grateful to the following projects for funding this work: "Análisis de la dinámica del polen atmosférico en Andalucía (P10-RNM-5958)", Research Project of Excellence of the Andalusia Regional Government; "Impacto del Cambio Climático en la fenología de especies vegetales del centro y sur de la Península Ibérica, FENOCLIM (CGL 2011-24146)" of the Spanish Ministry of Science and Innovation, and to the project "Aplicación y optimización del análisis polínico en el desarrollo de modelos de previsión de cosecha en olivo en Túnez (11-CAP2-0932)" of the Spanish Cooperation and Development Agency (AECID). Authors also are grateful to Ramón Areces Fundation (Madrid, Spain) by the post-doctoral grant of Dr. Aguilera. We appreciate the special contribution of Dr. José Guerrero-Casado.

\section{References}

Aguilera F (2012) Modelos de previsión precoz de cosecha en el olivo (Olea europaea L.) basados en información aerobiológica, fenológica y meteorológica: diseño experimental aplicado al olivar giennense. Instituto de Estudios Giennenses, Jaén

Aguilera F, Ruiz-Valenzuela L (2009) Study of the floral phenology of Olea europaea L. in Jaén province (SE Spain) and its relation with pollen emission. Aerobiologia 25:217-225. doi:10.1007/s10453009-9127-5

Aguilera F, Ruiz L, Fornaciari M, Romano B, Galán C, Oteros J, Ben Dhiab A, Msallem M, Orlandi F (2013) Heat accumulation period in the Mediterranean region: phenological response of the olive in different climate areas (Spain, Italy and Tunisia). Int J Biometeorol. doi:10.1007/s00484-013-0666-7

Allen RG, Pereira LS, Raes D, Smith M (1998) Crop evapotranspiration-guidelines for computing crop water requirements. FAO Irrigation and Drainage Paper 56, FAO, Rome, Italy, http://www. fao.org/docrep/X0490E/x0490e00.htm

Bacelar EA, Santos DL, Moutinho-Pereira JM, Lopes JI, Goncalves BC, Ferreita TC, Correia CM (2007) Physiological behaviour, oxidative damage and antioxidative protection of olive trees grown under different irrigation regimes. Plant Soil 292:1-12. doi:10.1007/ s11104-006-9088-1

Bacelar EA, Moutinho-Pereira JM, Goncalves BC, Lopes JI, Correia CM (2009) Physiological responses of different olive genotypes to drought conditions. Acta Physiol Plant 31:611-621. doi:10.1007/ s11738-009-0272-9

Barranco D, Fernández-Escobar R, Rallo L (2008) El Cultivo del olivo ( $\left.8^{\mathrm{a}} \mathrm{Ed}\right)$. Junta de Andalucía y Ediciones. Mundi-Prensa, Madrid

Bastiaanssen WGM, Ali S (2003) A new crop yield forecasting model based on satellite measurements applied across the Indus Basin, Pakistan. Agric Ecosyst Environ 94:321-340. doi:10.1016/S01678809(02)00034-8

Candau Fernández-Mensaque P, González-Minero FJ, Morales J, Tomas C (1998) Forecasting olive (Olea europaea) crop production by monitoring airborne pollen. Aerobiologia 14:185-190. doi:10.1007/ BF02694204

Cour P (1974) Nouvelles techniques de détection des flux et des retombées polliniques á la surface du sol. Pollen Spores 16:103-141

Cuevas J, Pinillos V, Polito VS (2009) Effective pollination period for 'Manzanillo'and 'Picual'olive trees. J Hortic Sci Biotechnol 84: 370-374 
Fei T, Wenbin W, Dandan L, Zhongxin C, Qing H, Tian X (2012) Yield estimation of winter wheat in North China Plain by using crop growth monitoring system (CGMS). In Agro-Geoinformatics (Agro-Geoinformatics). First International Conference on (pp 14). IEEE

Fornaciari M, Pieroni L, Orlandi F, Romano B (2002) A new approach to consider the pollen variable in forecasting yield models. Econ Bot 56:66-72. doi:10.1663/0013-0001(2002)056[0066:ANATCT]2.0. $\mathrm{CO} ; 2$

Fornaciari M, Orlandi F, Romano B (2005) Yield forecasting for olive trees. Agron J 97:1537-1542. doi:10.2134/agronj2005. 0067

Galán C, Cariñanos P, García-Mozo H, Alcázar P, Domínguez-Vilches E (2001) Model for forecasting Olea europaea L. airborne pollen in South-West Andalusia, Spain. Int J Biometeorol 45:59-63. doi:10. 1007/s004840100089

Galán C, Vázquez L, García-Mozo H, Domínguez E (2004) Forecasting olive (Olea europaea) crop yield based on pollen emission. Field Crop Res 86:43-51. doi:10.1016/S0378-4290(03)00170-9

Galán C, García-Mozo H, Vázquez L, Ruiz L, De La Guardia CD, Trigo M (2005) Heat requirement for the onset of the Olea europaea L. pollen season in several sites in Andalusia and the effect of the expected future climate change. Int J Biometeorol 49(3):184-188. doi:10.1007/s00484-004-0223-5

Galán C, Cariñanos P, Alcázar P, Domínguez-Vilches E (2007) Spanish Aerobiology Network (REA): management and quality manual. Servicio de publicaciones de la Universidad de Cordoba, Cordoba, Spain

Galán C, García-Mozo H, Vázquez L, Ruiz L, Díaz De La Guardia C, Domínguez-Vilches E (2008) Modeling olive crop yield in Andalusia, Spain. Agron J 100:98-104. doi:10.2134/agrojnl2006. 0345

García-Mozo H, Chuine I, Perez-Badía R, Galán C (2008) Aerobiological and meteorological factors influence on olive (Olea europaea L.) crop yield in Castilla-La Mancha (Central Spain). Aerobiologia 24: 13-18. doi:10.1007/s10453-007-9075-x

García-Mozo H, Orlandi F, Galán C, Fornaciari M, Romano B, Ruiz L, Diaz de la Guardia C, Trigo M, Chuine I (2009) Olive flowering phenology variation between different cultivars in Spain and Italy: modeling analysis. Theor appl climatol 95:385-395. doi:10.1007/ s00704-008-0016-6

García-Mozo H, Domínguez-Vílchez E, Galán C (2012) A model to account for variations in holm-oak (Quercus ilex subsp. ballota) acorn production in southern Spain. Ann Agric Environ Med 19: $411-416$

General Department of Agricultural Production (GDAP) (2011) http:// www.tn.gov/agriculture/

Giorgi F, Lionello P (2008) Climate change projections for the Mediterranean region. Global Planet Change 63:90-104. doi:10. 1016/j.gloplacha.2007.09.005

González-Minero FJG, Candau P, Morales J, Tomas C (1998) Forecasting olive crop production based on ten consecutive years of monitoring airborne pollen in Andalusia (southern Spain). Agric Ecosyst Environ 69:201-215. doi:10.1016/S0167-8809(98)00105-4

Hirst JM (1952) An automatic volumetric spore trap. Ann Appl Biol 39: 257-265. doi:10.1111/j.1744-7348.1952.tb00904.x

International Olive Council (IOC) (2011) http://www. internationaloliveoil.org/

ISTAT (2011) Instituto Nazionale di Statistica. http://agri.istat.it/

Keynan N, Waisel Y, Shomer A, Tamir R (1989) Forecasting pollen pollution: correlation with floral development. Ann Allergy 63: $417-420$

Lavalle C, Micale F, Houston TD, Camia A, Hiederer R, Lazar C, Conte C, Amatulli G, Genovese G (2009) Climate change in Europe. 3. Impact on agriculture and forestry A review. Agron Sustain Dev 29(3):433-446
Lavee SH (1996) World olive encyclopedia. International Olive Oil Council, 61-106

León-Ruiz E, Alcázar P, Domínguez-Vilches E, Galán C (2011) Study of Poaceae phenology in a Mediterranean climate. Which species contribute most to airborne pollen counts? Aerobiologia 27:37-50. doi:10.1007/s10453-010-9174-y

Melo-Abreu JP, Barranco D, Cordeiro AM, Tous J, Rogado BM, Villalobos FJ (2004) Modelling olive flowering date using chilling for dormancy release and thermal time. Agric For Meteorol 125: 117-127. doi:10.1016/j.agrformet.2004.02.009

Muñoz AF, Silva I, Tormo R (2000) The relationship between Poaceae pollination levels and cereal yields. Aerobiologia 16:281-286. doi: 10.1023/A:1007655223069

Orlandi F, Ferranti F, Romano B, Fornaciari M (2003) Olive pollination: flowers and pollen of two cultivars of Olea europaea. N Z J Crop Hortic 31:159-168. doi:10.1080/01140671.2003. 9514248

Orlandi F, García-Mozo H, Vázquez-Ezquerra L, Romano B, Domínguez-Vilches E, Galán C, Fornaciari M (2004) Phenological olive chilling requirements in Umbria (Italy) and Andalusia (Spain). Plant Biosyst 138:111-116. doi:10.1080/ 11263500412331283762

Orlandi F, Ruga L, Romano B, Fornaciari M (2005) Olive flowering as an indicator of local climatic changes. Theor Appl Climatol 81:169 176. doi:10.1007/s00704-004-0120-1

Orlandi F, Lanari D, Romano B, Fornaciari M (2006) New model to predict the timing of olive (Olea europaea) flowering: a case study in central Italy. N Z J Crop Hortic 34:93-99. doi:10.1080/01140671. 2006.9514392

Orlandi F, Carlo S, Bonofiglio T, Ruga L, Romano B, Fornaciari M (2010) Yield modelling in a Mediterranean species utilizing cause-effect relationships between temperature forcing and biological processes. Sci Hortic-Amst 123:412-417. doi:10.1016/j.scienta. 2009.09.015

Orlandi F, Garcia-Mozo H, Dhiab AB, Galán C, Msallem M, Fornaciari $M$ (2013) Olive tree phenology and climate variations in the Mediterranean area over the last two decades. Theor Appl Climatol. doi:10.1007/s00704-013-0892-2

Oteros J, García-Mozo H, Hervás C, Galán C (2013a) Biometeorological and autoregressive indices for predicting olive pollen intensity. Int J Biometeorol 57(2):307-316. doi:10.1007/ s00484-012-0555-5

Oteros J, García-Mozo H, Hervás-Martínez C, Galán C (2013b) Year clustering analysis for modelling olive flowering phenology. Int $\mathrm{J}$ Biometeorol 57(4):545-555. doi:10.1007/s00484-012-0581-3

Palm R (1995) Regression methods including the Eurostat Agromet model and time trends. Joint Research Centre of the E.U. Publication EUR 16008 EN. Office for Official Publications of the E.U. Luxembourg, 61-72

Pastor M, Orgaz F (1994) Riego deficitario del olivar: los programas de recorte de riego en olivar. Agricultura 746:768-776

Rallo L (1994) Evaluacion agronomica y obtencion de nuevas variedades de olivo. Olivicultura 62:17-28

Rapoport HF, Hammami S, Martins P, Pérez-Priego O, Orgaz F (2012) Influence of water deficits at different times during olive tree inflorescence and flower development. Environ Exp Bot 77:227-233. doi:10.1016/j.envexpbot.2011.11.021

Ribeiro H, Cunha M, Abreu I (2007) Improving early-season estimates of olive production using airborne pollen multisampling sites. Aerobiologia 23:71-78. doi:10.1007/s10453007-9050-6

Ribeiro H, Cunha M, Abreu I (2008) Quantitative forecasting of olive yield in Northern Portugal using a bioclimatic model. Aerobiologia 24:141-150. doi:10.1007/s10453-008-9094-2

Sicard P, Thibaudon M, Besancenot J-P, Mangin A (2012) Forecast models and trends for the main features of the Olea pollen season 
in Nice (South-eastern France) over the 1990-2009 period. Grana 51:52-62. doi:10.1080/00173134.2011.637577

SSYA (2011) Spanish statistical yearbook of agriculture. Ministry of Agriculture, Food and Environment. http://www.magrama. gob.es/es/

Vázquez LM, Galán C, Domínguez-Vilches E (2003) Influence of meteorological parameters on olea pollen concentrations in Córdoba
(South-western Spain). Int J Biometeorol 48(2):83-90. doi:10. 1007/s00484-003-0187-x

Vossen P (2007) Olive oil: history, production, and characteristics of the world's classic oils. HortSci 42:1093-1100

WGII IPCC Intergovernmental Panel on Climate Change (IPCC) (2007) Climate change 2007-impacts adaptation and vulnerability. IPCC, Cambridge 